\title{
Destruction and \\ human remains
}

Disposal and concealment in

genocide and mass violence

Edited by ÉLISABETH ANSTETT

and JEAN-MARC DREYFUS

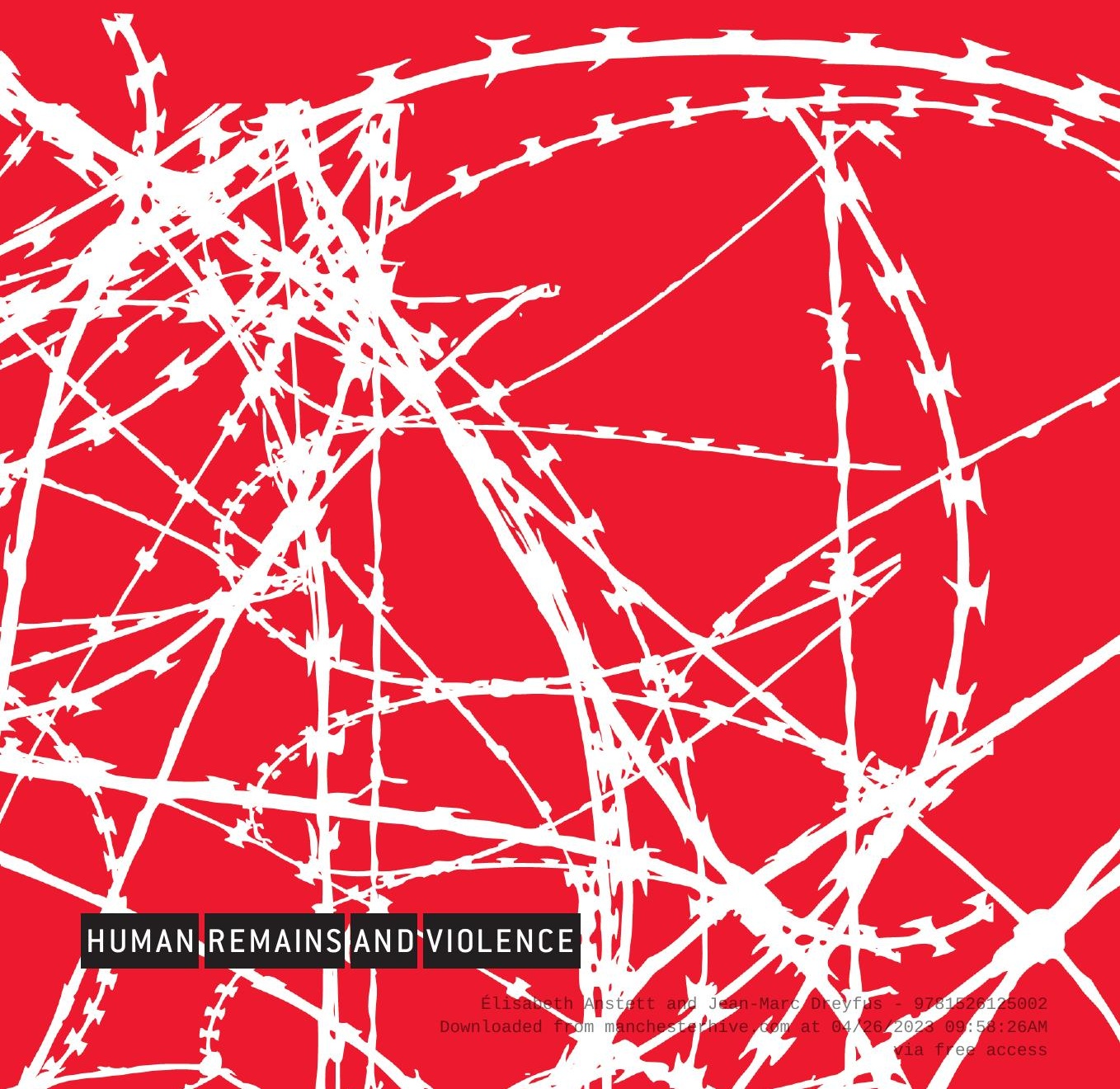




\section{Destruction and human remains}

\section{MANCHESTER 1824}

Manchester University Press 


\section{HUMAN REMAINS AND VIOLENCE}

Human remains and violence aims to question the social legacy of mass violence by studying how different societies have coped with the dead bodies resulting from war, genocide and state-sponsored brutality. However, rather paradoxically, given the large volume of work devoted to the body on the one hand, and to mass violence on the other, the question of the body in the context of mass violence remains a largely unexplored area and even an academic blind spot. Interdisciplinary in nature, Human remains and violence intends to show how various social and cultural treatments of the dead body simultaneously challenge common representations, legal practices and morality. This series aims to provide proper intellectual and theoretical tools for a better understanding of mass violence's aftermaths.

\section{Series editors}

Jean-Marc Dreyfus \& Élisabeth Anstett 


\section{Destruction and \\ human remains}

Disposal and concealment in genocide and mass violence

\section{Edited by}

Élisabeth Anstett \& Jean-Marc Dreyfus

Manchester University Press

Manchester and New York

distributed in the United States exclusively by Palgrave Macmillan 
While copyright in the volume as a whole is vested in Manchester University Press, copyright in individual chapters belongs to their respective authors.

This electronic version has been made freely available under a Creative Commons (CC-BY-NC-ND) licence, which permits non-commercial use, distribution and reproduction provided the author(s) and Manchester University Press are fully cited and no modifications or adaptations are made. Details of the licence can be viewed at https://creativecommons.org/licenses/by-nc-nd/3.0/

Published by Manchester University Press

Oxford Road, Manchester M13 9NR, UK

and Room 400, 175 Fifth Avenue, New York, NY 10010, USA

www.manchesteruniversitypress.co.uk

British Library Cataloguing-in-Publication Data

A catalogue record for this book is available from the British Library

Library of Congress Cataloging-in-Publication Data applied for

ISBN 9780719096020 hardback

First published 2014

The publisher has no responsibility for the persistence or accuracy of URLs for any external or third-party internet websites referred to in this book, and does not guarantee that any content on such websites is, or will remain, accurate or appropriate.

Typeset in Minion and Helvetica by R. J. Footring Ltd, Derby 